\title{
Virus-specific $\mathrm{CD8}^{+} \mathrm{T}$ cell numbers are maintained during $\boldsymbol{\gamma}$-herpesvirus reactivation in CD4-deficient mice
}

\author{
Philip G. Stevenson*, Gabrielle T. Belz*, John D. Altman $\dagger$, and Peter C. Doherty*末 \\ *The Department of Immunology, St Jude Children's Research Hospital, Memphis, TN 38105; and †'Emory Vaccine Center, and Department of Microbiology and \\ Immunology, Emory University School of Medicine, Atlanta, GA 30322

\begin{abstract}
The murine $\gamma$-herpesvirus 68 replicates in epithelial sites after intranasal challenge, then persists in various cell types, including $B$ lymphocytes. Mice that lack $\mathrm{CD4}^{+} \mathrm{T}$ cells $\left(\mathrm{I}-\mathrm{A}^{\mathrm{b}-/-}\right)$ control the acute infection, but suffer an ultimately lethal recrudescence of lytic viral replication in the respiratory tract. The consequences of $\mathrm{CD}^{+} \mathrm{T}$ cell deficiency for the generation and maintenance of murine $\gamma$-herpesvirus 68-specific $\mathrm{CD8}^{+}$set now have been analyzed by direct staining with viral peptides bound to major histocompatibility complex class I tetramers and by a spectrum of functional assays. Both acutely and during viral reactivation, the $\mathrm{CD8}^{+} \mathrm{T}$ cell responses in the $\mathrm{I}-\mathrm{A}^{\mathrm{b}-/-}$ group were no less substantial than in the I-A $\mathrm{A}^{\mathrm{b}+/+}$ controls. Indeed, virus-specific $\mathrm{CD8}^{+} \mathrm{T}$ cell numbers were increased in the lymphoid tissue of clinically compromised $I-A^{b-1-}$ mice, although relatively few of the potential cytotoxic $T$ lymphocyte effectors were recruited back to the site of pathology in the lung. Thus the viral reactivation that occurs in the absence of $\mathrm{CD} 4^{+} \mathrm{T}$ cells was not associated with any exhaustion of the virus-specific cytotoxic $\mathrm{T}$ lymphocyte response. It seems that $\mathrm{CD8}^{+} \mathrm{T}$ cells alone are insufficient to maintain long-term control of this persistent $\gamma$-herpesvirus.
\end{abstract}

The $\gamma$-herpesviruses $(\gamma$-HV) characteristically establish lifelong, asymptomatic infections, but can re-emerge to cause disease in acquired immune deficiencies, implying a delicate balance between viral persistence and immune control (1). The murine $\gamma$-HV, MHV-68, provides an experimental system for dissecting such processes (2, 3). Acute MHV-68 infection causes an illness similar to Epstein-Barr virus-induced infectious mononucleosis in humans, with splenomegaly (2), antigen-nonspecific B cell activation (4), and lymphocytosis (5). The B lymphocytes are a major reservoir of latent infection for both viruses $(1,6)$. It is also apparent that MHV-68 can persist in the respiratory epithelium (7) and in other cell types $(8,9)$.

Virus-specific $\mathrm{CD} 8^{+} \mathrm{T}$ cells play a major role in limiting the lytic phase of MHV-68 replication $(8,10)$. Mice that lack CD4 ${ }^{+}$ T cells as a consequence of homozygous disruption (11) of the $\mathrm{I}-\mathrm{A}^{\mathrm{b}}$ gene $\left(\mathrm{I}-\mathrm{A}^{\mathrm{b}-/-}\right)$ seem first to control the infection, but then develop a chronic, lethal wasting disease associated with rising virus titers in the lung (12). The present analysis quantitates the virus-specific $\mathrm{CD}^{+} \mathrm{T}$ cell response during the acute and persistent phases of MHV-68 infection in $\mathrm{I}-\mathrm{A}^{\mathrm{b}+/+}$ and $\mathrm{I}-\mathrm{A}^{\mathrm{b}-/-}$ mice. The findings have implications both for the idea that the exhaustion of $\mathrm{CD}^{+} \mathrm{T}$ cells (13) is a necessary feature of chronic infections and for the debate on the role of antigen persistence in the maintenance of cytotoxic $\mathrm{T}$ lymphocyte precursor (pCTL) numbers (14-16).

The publication costs of this article were defrayed in part by page charge payment. This article must therefore be hereby marked "advertisement" in accordance with 18 U.S.C. $\$ 1734$ solely to indicate this fact.

(C) 1998 by The National Academy of Sciences 0027-8424/98/9515565-6\$2.00/0 PNAS is available online at www.pnas.org.

\section{MATERIALS AND METHODS}

Mice, Sampling, and Virus Infection. Female C57BL/6J mice $\left(\mathrm{I}-\mathrm{A}^{\mathrm{b}+/+}\right)$ (The Jackson Laboratory) and major histocompatibility complex class II-deficient (I-A $\left.\mathrm{A}^{\mathrm{b}-/-}\right)$ mice were, except for exposure to MHV-68, kept under specific pathogenfree conditions. The mice were anesthetized with Avertin and infected intranasally with 600 plaque-forming units of MHV-68 at 8-12 weeks of age. Inflammatory cells were obtained from the lung by bronchoalveolar lavage (BAL), and single cell suspensions were made from the mediastinal lymph nodes and spleen (4).

Limiting Dilution Assay (LDA). Spleen cells from naive C57BL/6J mice were infected with MHV-68 [0.1 plaqueforming unit (pfu)/cell] for $1 \mathrm{hr}$ in RPMI (Life Technologies, Grand Island, NY), supplemented (complete medium) with penicillin $(60 \mu \mathrm{g} / \mathrm{ml})$, glutamine $(2 \mathrm{mM}), 10 \%$ fetal calf serum (HyClone), and 2-mercaptoethanol $(30 \mu \mathrm{M})$. They were washed once, irradiated $(3,000 \mathrm{rads})$, and incubated $(5 \times$ $10^{5} / 200-\mu$ l culture) with $2 \times$ dilutions of responder cells in complete medium at $37^{\circ} \mathrm{C}$ with $5 \% \mathrm{CO}_{2}$. Recombinant interleukin 2 (10 units $/ \mathrm{ml}$, Boehringer Mannheim) was added at day 0 and day 5 of culture. The microcultures were assayed on day 7, by using H-2 embryonic fibroblasts (2214-CRL, ATCC) that were infected with MHV-68 $(10 \mathrm{pfu} / \mathrm{cell})$ for $2 \mathrm{hr}$ at $37^{\circ} \mathrm{C}$, labeled with ${ }^{51} \mathrm{Cr}$ for $1 \mathrm{hr}$ at $37^{\circ} \mathrm{C}\left(0.2 \mathrm{mCi} / 10^{6}\right.$ cells, Amersham), and dispensed (5,000 targets/well) after two washes into 24 individual replicates for each dilution of responder cells. Supernatants were harvested $5 \mathrm{hr}$ later for $\gamma$-counting. Positive wells were taken as those with counts $>3$ SD above the mean for 24 wells containing only feeder cells and targets. The pCTL frequencies then were determined by a regression plot of the $\log _{10}$ fraction of the negative wells against mean cell number per well, with the correlation coefficient $\left(r^{2}\right)>0.9$ in each case.

Flow Cytometry of Total and Virus-Specific $\mathrm{CD8}^{+}{ }^{+} \mathrm{T}$ Cells. To determine total $\mathrm{CD}^{+} \mathrm{T}$ cell numbers, lymphocyte populations were washed in ice-cold PBS, stained with anti-CD8fluorescein isothiocyanate and anti-CD62L-phycoerythrin (PE) (PharMingen), washed again, and analyzed on a FACScan with Cellquest software (Becton-Dickinson). Virusspecific $\mathrm{CD}^{+} \mathrm{T}$ cells were identified by using two viral peptide epitopes: AGPHNDMEI (ORF 6, H-2D ${ }^{\mathrm{b}}$-restricted) and TSINFVKI (ORF 61, H-2K $\mathrm{K}^{\mathrm{b}}$-restricted), referred to as p56 and p79, respectively (unpublished data). By analogy with other HVs, both ORF 6 and ORF 61 encode early lytic cycle proteins. Recombinant $\mathrm{H}-2 \mathrm{D}^{\mathrm{b}}$ and $\mathrm{H}-2 \mathrm{~K}^{\mathrm{b}}$ molecules with a BirA biotinylation motif substituted for the carboxyl-terminal transmembrane domain (17) were refolded with human $\beta_{2}$

Abbreviations: BAL, bronchoalveolar lavage; CTL, cytotoxic T lymphocyte; eCTL, CTL effector; HV, herpesvirus; I-A ${ }^{\mathrm{b}-/-}, \mathrm{C} 57 \mathrm{BL} / 6 \mathrm{~J}$ mice homozygous for disruption of the I- $\mathrm{A}^{\mathrm{b}}$ gene; IFN- $\gamma$, interferon $\gamma$; LDA, limiting dilution analysis; MHV-68, murine $\gamma$-HV 68; pCTL, CTL precursor.

末To whom reprint requests should be addressed at: St. Jude Children's Research Hospital, 332 No. Lauderdale, Memphis, TN 38105. e-mail: peter.doherty@stjude.org. 


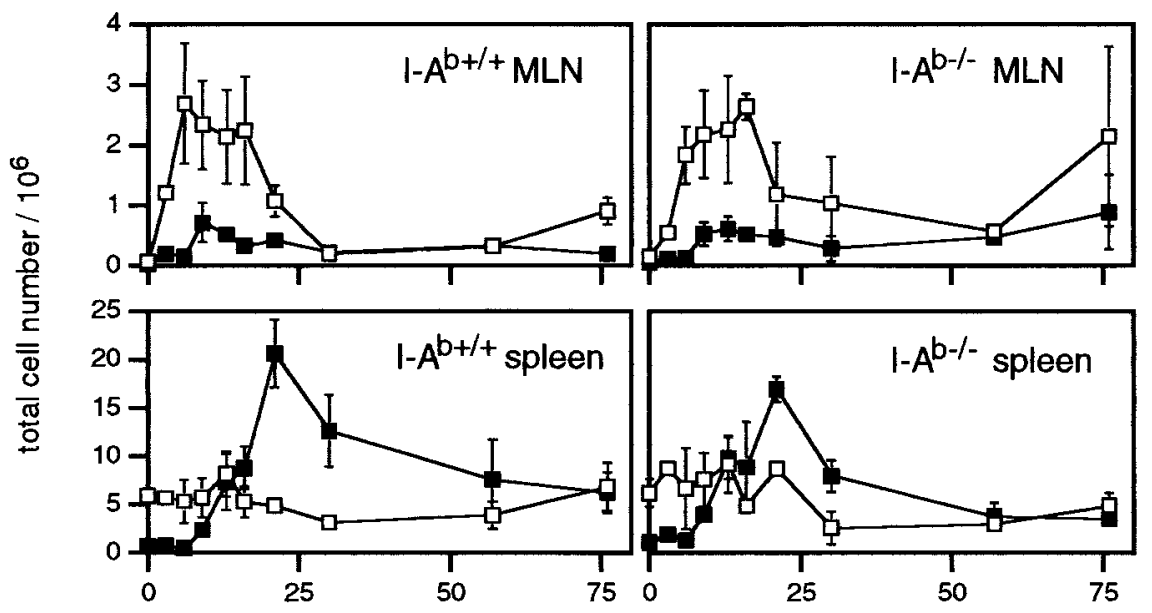

day after i.n. MHV-68

FIG. 1. Activation status and numbers of $\mathrm{CD} 8^{+} \mathrm{T}$ cells from the mediastinal lymph nodes and spleen of $\mathrm{I}-\mathrm{A}^{\mathrm{b}+/+}$ and I-A $\mathrm{A}^{\mathrm{b}-/-}$ mice infected intranasally with MHV-68. The samples were pooled from 1-3 mice at each time point, and the numbers (per mouse) of activated/memory $\left(\mathrm{CD} 62 \mathrm{~L}^{\mathrm{lo}}\right)(\boldsymbol{\square})$ and naive $\left(\mathrm{CD} 62 \mathrm{~L}^{\mathrm{hi}}\right)(\square) \mathrm{CD}^{+} \mathrm{T}$ cells were calculated from the total counts and the \% determined by FACS analysis. Each point is the mean $\pm \mathrm{SD}$ of $2-6$ experiments.

microglobulin plus the appropriate viral peptide, biotinylated with BirA, and complexed at a 4:1 molar ratio with Neutravidin-PE (Molecular Probes). Lymphocytes were stained for $30 \mathrm{~min}$ at room temperature with the tetrameric complexes in $\mathrm{PBS} / \mathrm{BSA} /$ azide, stained for $30 \mathrm{~min}$ on ice with CD8-tricolor (Caltag, Burlingame, CA), washed once, and analyzed as above.

Virus-specific interferon $\gamma(\operatorname{IFN}-\gamma)$ production $(18,19)$ was assayed by culturing lymphocytes for $6 \mathrm{hr}$ in complete medium with $10 \mu \mathrm{g} / \mathrm{ml}$ of brefeldin A (Epicentre Technologies, Madison, WI) in the presence or absence of the p56 or p 79 peptide $(1 \mu \mathrm{M})$. The responder cells then were washed once in PBS/Brefeldin A $(10 \mu \mathrm{g} / \mathrm{ml})$, stained with anti-CD8fluorescein isothiocyanate (PharMingen), washed again, fixed in $1 \%$ formaldehyde in PBS for $20 \mathrm{~min}$, washed, placed in PBS $/ 0.5 \%$ saponin (Sigma) for $10 \mathrm{~min}$, and incubated with anti-IFN- $\gamma$-phycoerythrin (PharMingen). The specificity of staining was confirmed in separate control experiments (not shown) by blocking with excess recombinant IFN- $\gamma$. In each case, the percentage of $\mathrm{CD}^{+} \mathrm{IFN}-\gamma^{+}$without peptide $(<0.5 \%)$ was subtracted from the percentage of CD $8^{+}$IFN- $\gamma^{+}$ with peptide to give the percentage of peptide-specific $\mathrm{CD} 8^{+}$ $\mathrm{T}$ cells. Neither MHV-68-immune $\mathrm{CD} 8^{-}$cells nor $\mathrm{CD} 8^{+} \mathrm{T}$ cells from mice that had not been exposed to MHV-68 showed a peptide-specific response.

ELISpot Analysis. Nitrocellulose-coated 96-well plates (Millipore) were coated overnight at $4^{\circ} \mathrm{C}$ with rat anti-mouse IFN- $\gamma(10 \mu \mathrm{g} / \mathrm{ml}$, PharMingen $)$, washed five times with PBS, and blocked for $1 \mathrm{hr}$ at $37^{\circ} \mathrm{C}$ with complete medium. Feeder cells were incubated for $1 \mathrm{hr}$ at $37^{\circ} \mathrm{C}$ in complete medium with $1 \mu \mathrm{M}$ p56 or p79, washed twice, and added $\left(5 \times 10^{5} /\right.$ well $)$ to duplicate $3 \times$ dilutions $\left(1 \times 10^{4}-1 \times 10^{5} /\right.$ well $)$ of responder cells. Each effector cell dilution also was incubated with unpulsed feeder cells. Samples were incubated for $40-44 \mathrm{hr}$ in complete medium with 20 units $/ \mathrm{ml}$ of interleukin 2 at $37^{\circ} \mathrm{C}$ and $5 \% \mathrm{CO}_{2}$. Secreted cytokine was detected with biotinylated rat anti-mouse IFN- $\gamma$ (PharMingen) and streptavidin-alkaline phosphatase (Dako). The plates were washed five times with PBS $/ 0.05 \%$ Tween 20 after each incubation, and spots visualized with 5-bromo-4-chloro-3-indolyl phosphate/nitroblue tetrazolium substrate (Sigma) were counted microscopically. The mean number of spots for feeders with no peptide $(<10 /$ well) was subtracted from the mean number of spots with peptide-pulsed feeders $(20-200$ spots/well) to give the number of antigen-specific cells. In separate control experi- ments (not shown), anti-CD8 depletion reduced the number of specific spots by $>95 \%$, whereas neither CD4 nor NK1.1 depletion had a significant effect.

\section{RESULTS}

The current experiments quantitate the MHV-68-specific $\mathrm{CD}^{+} \mathrm{T}$ cell response by using techniques that had not been developed for this virus when we earlier analyzed the characteristics of virus growth and latency in $\mathrm{I}-\mathrm{A}^{\mathrm{b}-/-}$ and $\mathrm{I}-\mathrm{A}^{\mathrm{b}+/+}$ mice (12). The intent was to determine whether the viral recrudescence seen in the $\mathrm{I}-\mathrm{A}^{\mathrm{b}-1-}$ group resulted from a loss of virus-specific $\mathrm{CD}^{+} \mathrm{T}$ cells.

Total $\mathrm{CD8}^{+} \mathrm{T}$ Cell Numbers. The numbers of activated/ memory $\left(\mathrm{CD}^{2} \mathrm{~L}^{\mathrm{lo}}\right) \mathrm{CD}^{+}$lymphocytes peaked earlier in the regional mediastinal lymph nodes than in the spleens of the I-A $\mathrm{A}^{\mathrm{b}+/+}$ mice (Fig. 1). Although the expansion (5) of activated,

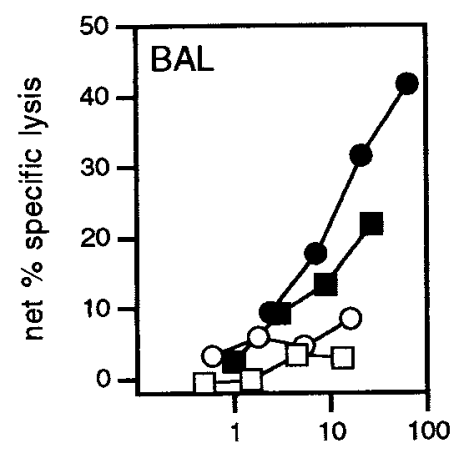

Effector :Target ratio

FIG. 2. Virus-specific eCTL activity in the BAL. The cells were pooled from seven mice, either early (day $13, \bullet \mathbf{\square})$ or late (day $76, \bigcirc \square)$ in infection of $\mathrm{I}-\mathrm{A}^{\mathrm{b}-1-}(\bullet)$ or $\mathrm{I}-\mathrm{A}^{\mathrm{b}+/+}$ mice $(\square)$. Flow cytometric analysis for the $\% \mathrm{CD}^{+}$in populations recovered by BAL on day 13 and day 76 , respectively, showed typically $40 \%$ and $20 \%$ in the I-A ${ }^{\mathrm{b}+/+}$ mice, and $75 \%$ and $50 \%$ in the I- $\mathrm{A}^{\mathrm{b}-1-}$ mice. The mean \pm SD total cell counts per mouse from the BAL on day 13 and day 76 were $2.6 \pm 0.8 \times$ $10^{5}$ and $0.6 \pm 0.1 \times 10^{5}$ in the I-A $\mathrm{A}^{\mathrm{b}+/+}$ group, and $2.0 \pm 0.8 \times 10^{5}$ and $1.4 \pm 0.8 \times 10^{5}$ in the $\mathrm{I}-\mathrm{A}^{\mathrm{b}-1-}$ group. The results shown are representative of three separate experiments. Net $\%$ specific lysis $=\%$ specific lysis of MHV-68-infected targets - \% specific lysis of uninfected targets. Specific lysis of uninfected targets was $<5 \%$. 
day 13

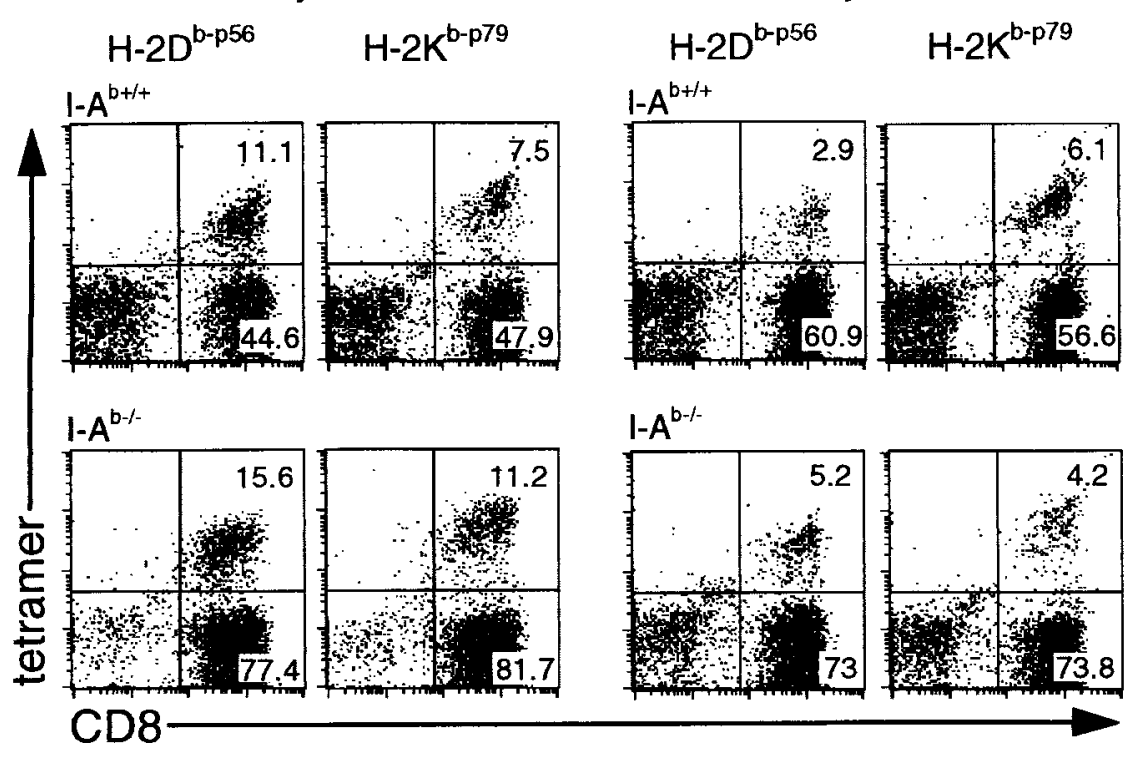

FIG. 3. Enumeration of peptide-specific $\mathrm{CD}^{+} \mathrm{T}$ cells in the BAL during acute and recrudescent infection by staining with tetrameric major histocompatibility complex class I/peptide complexes. The results show one representative experiment from the data illustrated in Table 1 . No significant staining $(<0.2 \%)$ was observed either with the MHV-68 tetramers by using lymphocytes from naive mice, or with $\mathrm{H}_{-2} \mathrm{D}^{\mathrm{b}-\mathrm{ASNENMETM}}$ (influenza virus epitope) or H-2K $\mathrm{K}^{\mathrm{b}-\mathrm{FAPGNYPAL}}$ (Sendai virus epitope) tetramers (19) using the MHV-68-immune lymphocytes. The identity of the tetramer-positive $\mathrm{CD}^{+}$cells as $\mathrm{T}$ cells was further confirmed by staining with $\mathrm{CD} 3$, $\mathrm{T}$ cell receptor beta chain, and Thy-1 (data not shown).

$\mathrm{V} \beta 4^{+} \mathrm{CD}^{+} \mathrm{T}$ cells associated with MHV-68 infection does not occur in $\mathrm{I}-\mathrm{A}^{\mathrm{b}-1-}$ mice, the absence of $\mathrm{CD} 4^{+} \mathrm{T}$ cells from the I-A $\mathrm{A}^{\mathrm{b}-/-}$ group did not greatly compromise the increase in counts for the CD8 ${ }^{+} \mathrm{CD} 62 \mathrm{~L}^{\text {lo }}$ set. This population persisted in both lymphoid sites at higher prevalence than in age-matched, uninfected controls.

CTL Activity of Freshly Isolated T cells. The lack of CD4 ${ }^{+}$ $\mathrm{T}$ cells led to no deficit in the recruitment of virus-specific $\mathrm{CD}^{+} \mathrm{T}$ cells during the acute phase of the host response in the lung (see legend to Fig. 2). Indeed, higher levels of effector CTL (eCTL) activity were recovered from the respiratory tract of the $\mathrm{I}-\mathrm{A}^{\mathrm{b}-/-}$ mice, presumably reflecting the delay in viral clearance (12). However, eCTL activity was low in the I-A ${ }^{\mathrm{b}-/-}$ mice at late time points (Fig. 2), when there was clinical illness (ruffled fur, weight loss) and infectious virus in lung homogenates (not shown).

Direct Staining with the Tetramers. The staining profiles for the p56- and p79-specific CD8 ${ }^{+} \mathrm{T}$ cells in the BAL populations recovered at day 13 or day 115 after infection are shown in Fig. 3 and Table 1 . In contrast to the acute infection, there was relatively little recruitment of the antigen-specific $\mathrm{CD}^{+}$set to the lungs of the $\mathrm{I}-\mathrm{A}^{\mathrm{b}-/-}$ mice during viral recrudescence, consistent with the low levels of eCTL activity (Fig. 2). However, the numbers of virus-specific $\mathrm{CD}^{+} \mathrm{T}$ cells in the spleens of the I-A $\mathrm{A}^{\mathrm{b}-/-}$ mice increased late in the course of the disease process, an effect that was particularly apparent with the p56 epitope (Table 1 ).

Intracytoplasmic Staining for IFN- $\boldsymbol{\gamma}$. Short-term, in vitro stimulation established that the $\mathrm{CD}^{+} \mathrm{T}$ cells detected by staining with tetrameric complexes (Fig. 3, Table 1) were functional (Fig. 4 , Table 2). Indeed, the numbers producing IFN- $\gamma$ in the acute BAL generally were higher than those staining with tetramers, perhaps reflecting some down-regulation of T cell receptor levels on this highly activated population. Adding the $\%$ IFN- $\gamma^{+}$for the p56 and p79 peptide stimulations at day 13 showed $54.3 \pm 11.3 \%$ and $43.0 \pm 12.8 \%$ of the $\mathrm{CD}^{+} \mathrm{T}$ cells in the BAL to be MHV-68-specific in the $\mathrm{I}-\mathrm{A}^{\mathrm{b}+/+}$ and $\mathrm{I}-\mathrm{A}^{\mathrm{b}-/-}$ mice, respectively (mean \pm SD from three experiments). By 80-90 days after infection, $10.9 \pm 3.4$ and $10.3 \pm 1.3$ of the $\mathrm{CD}^{+} \mathrm{T}$ cells in the BAL of the I-A $\mathrm{A}^{\mathrm{b}+/+}$ and $\mathrm{I}-\mathrm{A}^{\mathrm{b}-1-}$ mice, respectively, responded either to $\mathrm{p} 56$ or to $\mathrm{p} 79$ (mean $\pm \mathrm{SD}$ from three experiments). The IFN- $\gamma$ staining also corresponded to the tetramer staining in showing increased numbers of $\mathrm{p} 56$-specific $\mathrm{CD}^{+} \mathrm{T}$ cells in the spleens of the $\mathrm{I}-\mathrm{A}^{\mathrm{b}-1-}$ mice during viral recrudescence. Thus, the late disease in these mice was not obviously associated with a loss of $\mathrm{CD}^{+} \mathrm{T}$ cell function.

Table 1. MHV-68-specific CD8 ${ }^{+} \mathrm{T}$ cells enumerated by tetramer staining during acute and recrudescent infection

\begin{tabular}{|c|c|c|c|c|c|}
\hline \multirow[b]{3}{*}{ Mice } & \multirow[b]{3}{*}{ Time } & \multicolumn{4}{|c|}{ Percentage tetramer positive of the total $\mathrm{CD} 8^{+}$population } \\
\hline & & \multicolumn{2}{|c|}{ BAL } & \multicolumn{2}{|c|}{ Spleen } \\
\hline & & $\mathrm{H}-2 \mathrm{D}^{\mathrm{b}-\mathrm{p} 56}$ & $\mathrm{H}-2 \mathrm{~K}^{\mathrm{b}-\mathrm{p} 79}$ & $\mathrm{H}-2 \mathrm{D}^{\mathrm{b}-\mathrm{p} 56}$ & $\mathrm{H}-2 \mathrm{~K}^{\mathrm{b}-\mathrm{p} 79}$ \\
\hline \multirow[t]{2}{*}{$\overline{\mathrm{I}-\mathrm{A}^{\mathrm{b}+/+}}$} & Day 13 & $14.6 \pm 3.9$ & $14.4 \pm 3.1$ & $4.5 \pm 1.8$ & $4.2 \pm 2.5$ \\
\hline & Day $90-115$ & $3.2 \pm 1.9$ & $8.3 \pm 1.9$ & $0.9 \pm 0.3$ & $1.6 \pm 0.5$ \\
\hline \multirow[t]{2}{*}{$\mathrm{I}-\mathrm{A}^{\mathrm{b}-/-}$} & Day 13 & $10.4 \pm 4.4$ & $10.5 \pm 4.7$ & $4.6 \pm 2.0$ & $4.9 \pm 2.5$ \\
\hline & Day $90-115$ & $5.4 \pm 1.5$ & $5.1 \pm 0.4$ & $3.5 \pm 0.8$ & $2.9 \pm 1.4$ \\
\hline
\end{tabular}

The spleen populations were enriched for the $\mathrm{CD}^{+}$set $(>70 \% \mathrm{CD} 8)$ before assay by in vitro depletion with the GK1.5 mAb to CD4, followed by sheep-anti-rat Ig and sheep-anti-mouse Ig coated magnetic beads (Dynal). In each experiment, BAL samples were pooled from 3-6 mice, and spleen cells were analyzed from three separate individuals or from three pairs for each group. The results show the mean \pm SD for three experiments. No significant difference was observed across the range of late time points used (90-115 days). At these times, the prevalence of p56-specific $\mathrm{CD} 8^{+} \mathrm{T}$ cells was significantly higher in the $\mathrm{I}-\mathrm{A}^{\mathrm{b}-/-}$ mice than in the $\mathrm{I}-\mathrm{A}^{\mathrm{b}+/+}$ controls $(P<0.0001$ by $t$ test $)$. 
day 13

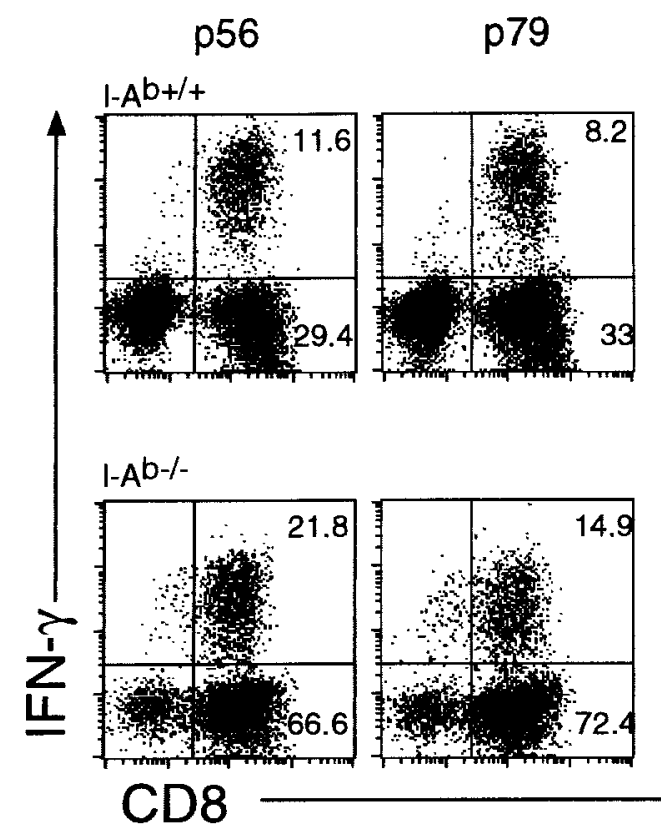

day 89

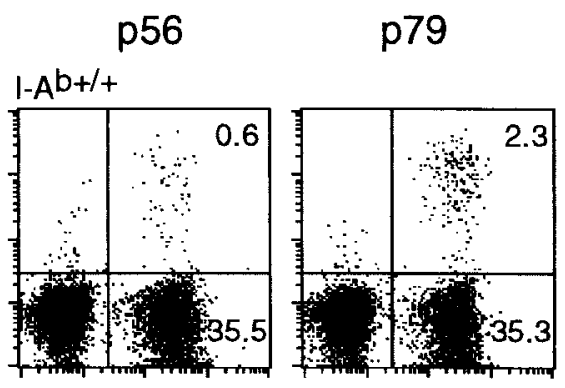

I-A b-I-
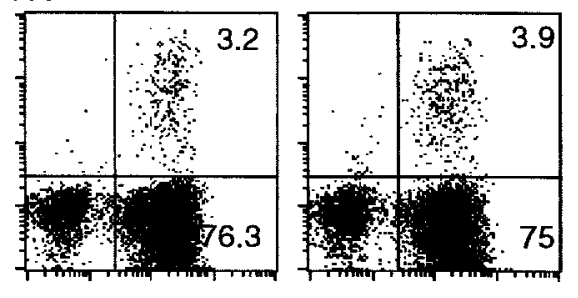

FIG. 4. IFN- $\gamma$-producing cells in the BAL at early and late time points. The BAL populations were pooled from five mice, stimulated for 6 hr with peptide in the presence of Brefeldin A, then stained for CD8 and IFN- $\gamma$ and analyzed by flow cytometry. The control values (no peptide or irrelevant peptide) were always $<0.5 \%$, as was the MHV-68 peptide-specific response of BAL cells from C57BL/6J mice infected with influenza A/X31 (not shown). Equivalent results were obtained in five further experiments.

ELISpot Analysis for Peptide-Specific T Cells. Functional, peptide-specific $\mathrm{CD}^{+} \mathrm{T}$ cells were also detectable by ELISpot assay $(18,20)$ during viral recrudescence in the $\mathrm{I}-\mathrm{A}^{\mathrm{b}-1-}$ mice (Fig. 5). The responses to both epitopes were maximal acutely and then declined, presumably reflecting a drop in antigen load. The significantly higher prevalence of p56-specific responders in the $\mathrm{I}-\mathrm{A}^{\mathrm{b}-1-}$ mice at day $25(P<0.005$ by $t$ test $)$ could reflect their delayed pulmonary viral clearance (12) relative to the $\mathrm{I}-\mathrm{A}^{\mathrm{b}+/+}$ controls. At late time points, $\mathrm{p} 56-$ specific cells also looked to be more prevalent in the I-A ${ }^{\mathrm{b}-/-}$ than in the $\mathrm{I}-\mathrm{A}^{\mathrm{b}+/+}$ mice, although this prevalence did not reach statistical significance $(P=0.054$ by $t$ test $)$.

pCTL Frequencies Determined by LDA. Quantitating the MHV-68-specific CD8 ${ }^{+}$set by LDA (4) indicated no loss of virus-specific pCTL during viral recrudescence in the I-A $\mathrm{A}^{\mathrm{b}-1-}$ mice (Fig. 6). Frequencies were maximal between 10 and 15

Table 2. MHV-68-specific CD8 ${ }^{+} \mathrm{T}$ cell response in the BAL and spleen

Percentage IFN- $\gamma$ positive of the total $\mathrm{CD} 8{ }^{+}$population after a $6-\mathrm{hr}$ incubation with peptide

\begin{tabular}{|c|c|c|c|c|c|}
\hline \multirow[b]{3}{*}{ Mice } & \multirow[b]{3}{*}{ Time } & \multirow{2}{*}{\multicolumn{2}{|c|}{ BAL }} & & \\
\hline & & & & \multicolumn{2}{|c|}{ Spleen } \\
\hline & & $\mathrm{p} 56$ & p79 & $\mathrm{p} 56$ & p79 \\
\hline \multirow[t]{3}{*}{$\overline{\mathrm{I}-\mathrm{A}^{\mathrm{b}+/+}}$} & Day 14 & 24.2 & 23.3 & $2.2 \pm 0.9$ & $2.3 \pm 1.4$ \\
\hline & Day 22 & 10.8 & 22.4 & $1.2 \pm 0.5$ & $3.5 \pm 0.8$ \\
\hline & Day 81 & 3.4 & 11.1 & $0.9 \pm 0.2$ & $2.7 \pm 0.5$ \\
\hline \multirow[t]{3}{*}{$\mathrm{I}-\mathrm{A}^{\mathrm{b}-/-}$} & Day 14 & 20.9 & 10.0 & $3.3 \pm 1.1$ & $3.4 \pm 2.2$ \\
\hline & Day 22 & 5.4 & 15.9 & $1.7 \pm 0.7$ & $2.6 \pm 0.9$ \\
\hline & Day 81 & 5.6 & 4.9 & $4.2 \pm 0.5$ & $2.6 \pm 0.8$ \\
\hline
\end{tabular}

The spleen populations were enriched for the $\mathrm{CD} 8^{+}$set before staining as described in the legend to Table 1 . All samples then were analyzed for response to the p56 and p79 MHV-68-peptides as described in the legend to Fig. 4. The spleen results are the mean \pm SD for groups of five mice, while the BAL populations were analyzed as pools. At day 81 , paired $t$ tests showed a significantly greater response to $\mathrm{p} 56$ in the $\mathrm{I}-\mathrm{A}^{\mathrm{b}-/-}$ mice $(P<0.0001)$. These results were reproduced in four further experiments. days after infection in both the $\mathrm{I}-\mathrm{A}^{\mathrm{b}+/+}$ and $\mathrm{I}-\mathrm{A}^{\mathrm{b}-/-}$ mice, fell by 21-30 days after infection, and remained at these lower levels for as long as 600 days in the $\mathrm{I}-\mathrm{A}^{\mathrm{b}+/+}$ group and 100 days in the I- $\mathrm{A}^{\mathrm{b}-1-}$ mice, which suffered significant mortality from this time onward. The total pCTL numbers determined by ELISpot analysis with the p56 and p79 peptides of MHV-68

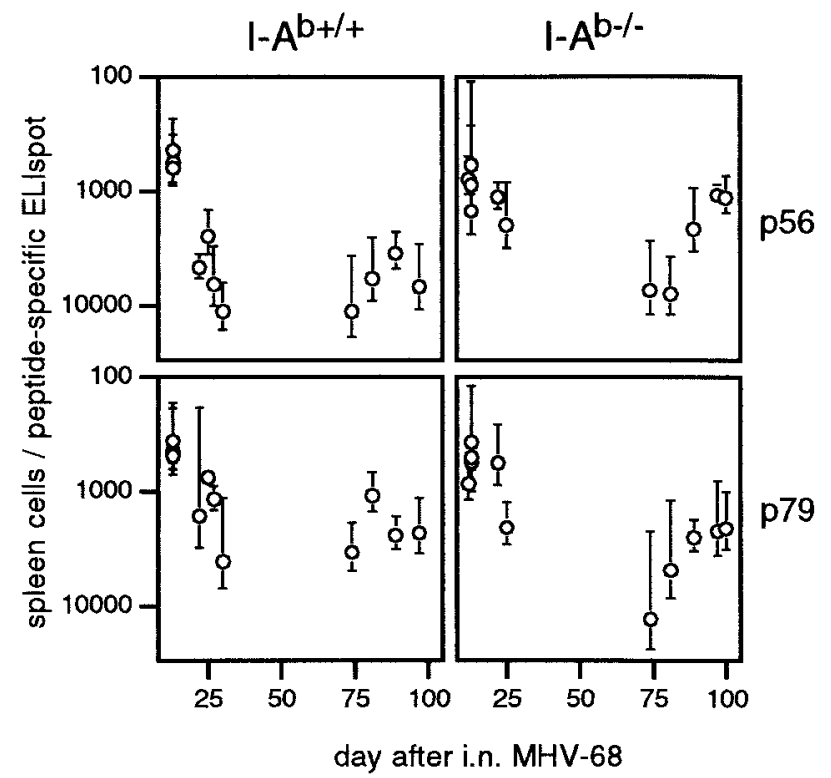

FIG. 5. Determination of MHV-68-peptide-specific $\mathrm{CD}^{+} \mathrm{T}$ cell prevalence by ELISpot analysis. Dilutions of splenic mononuclear cells were incubated with feeders, pulsed with the MHV-68 peptides $\mathrm{p} 56$ or $\mathrm{p} 79$, on plates coated with a mAb to IFN- $\gamma$. The number of peptidespecific spots developed with a biotinylated rat anti-mouse IFN- $\gamma$ after $40-44 \mathrm{hr}$ of culture was determined by subtracting the values for control cultures without the relevant peptide. Mean \pm SD reciprocal frequencies from 5-6 individual spleens per time point are shown. Reciprocal peptide-specific frequencies for naive I-A $\mathrm{A}^{\mathrm{b}+/+}$ and $\mathrm{I}-\mathrm{A}^{\mathrm{b}-/-}$ mice were $>100,000$. 


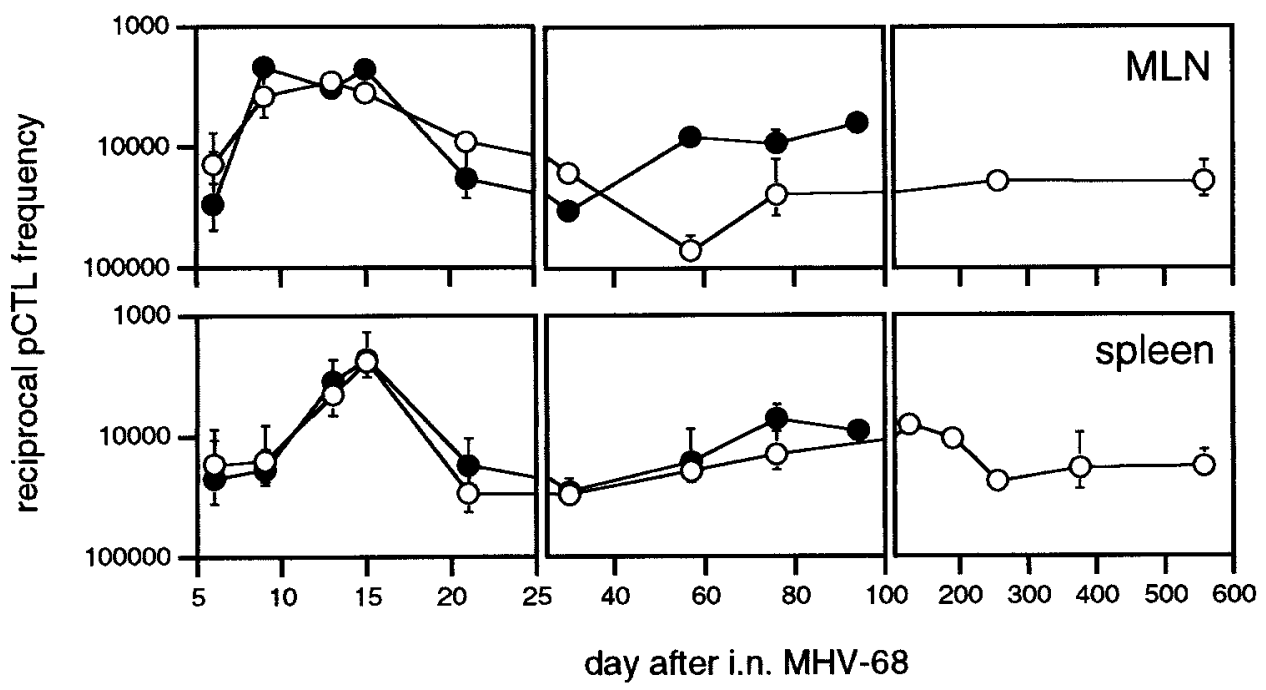

FIG. 6. Determination of MHV-68-specific pCTL frequencies by LDA. Lymphocyte populations were stimulated in vitro for 7 days, and then assayed for eCTL activity by using MHV-68-infected $\mathrm{H}-2^{\mathrm{b}}$ targets. Values for $\mathrm{I}-\mathrm{A}^{\mathrm{b}+/+}(\mathrm{O})$ or I-A $\mathrm{A}^{\mathrm{b}-/-}(\bullet)$ mice are mean \pm SEM of the reciprocal pCTL frequencies from 4-8 individual spleens, or 2-3 mediastinal lymph node samples pooled from at least three mice. Reciprocal virus-specific pCTL frequencies for naive I-A $\mathrm{A}^{\mathrm{b}+/+}$ and $\mathrm{I}-\mathrm{A}^{\mathrm{b}-1-}$ mice were $>100,000$. The $\mathrm{I}-\mathrm{A}^{\mathrm{b}-/-}$ mice generally died between 100 and 200 days after infection.

(Fig. 5) were clearly higher than for the virus-based LDA (Fig. $6)$, in agreement with the relationship established between these assays for lymphocytic choriomeningitis virus infection $(18,20)$. In contrast to the ELISpot assay (Fig. 5, p56) that probably detects both eCTL and pCTL $(18,20)$, there was little difference between the $\mathrm{I}-\mathrm{A}^{\mathrm{b}+/+}$ and $\mathrm{I}-\mathrm{A}^{\mathrm{b}-1-}$ groups in the pCTL numbers measured by LDA (Fig. 6), during either acute or persistent infection. It seems that eCTL rather than $\mathrm{pCTL}$ numbers increase in response to the higher lytic antigen loads (12) in the $\mathrm{I}-\mathrm{A}^{\mathrm{b}-/-}$ mice. Overall, the results did not indicate that the $\mathrm{CD}^{+} \mathrm{T}$ cells recovered from the $\mathrm{I}-\mathrm{A}^{\mathrm{b}-/-}$ mice are functionally defective in any sense.

\section{DISCUSSION}

The key finding from these experiments is that, no matter what the assay system, there is no evidence that MHV-68 recrudescence in the absence of CD4 ${ }^{+} \mathrm{T}$-help is associated with an exhaustion of the $\mathrm{CD}^{+} \mathrm{T}$ cell response, at least as regards lytic phase antigens. Neither the generation nor the maintenance of virus-specific $\mathrm{CD}^{+} \mathrm{T}$ cell numbers was impaired in the $\mathrm{I}-\mathrm{A}^{\mathrm{b}-/-}$ mice. This finding is consistent with previous evidence that virus infections elicit $\mathrm{CD} 8^{+} \mathrm{CTL}$ responses even in the absence of CD4 ${ }^{+} \mathrm{T}$ cells (21-23). Specifically, IFN- $\gamma$ (24) produced by antiviral NK cells (25) may substitute for $\mathrm{CD}^{+}$ $\mathrm{T}$ cell-derived cytokines.

Even when $\mathrm{CD}^{+} \mathrm{T}$ cells seem to be essential for $\mathrm{CD} 8^{+} \mathrm{T}$ cell-mediated protection against viruses, this need does not necessarily reflect a requirement for $\mathrm{CD} 4^{+} \mathrm{T}$ help in priming the $\mathrm{CD}^{+} \mathrm{T}$ cell compartment. Production of IFN- $\gamma$ by $\mathrm{CD}^{+}$ $\mathrm{T}$ cells in herpes simplex virus infection overcomes the viral inhibition of major histocompatibility complex class I antigen presentation (26), whereas the CTL exhaustion observed in lymphocytic choriomeningitis virus-infected $\mathrm{CD}^{+} \mathrm{T}$ celldeficient mice $(27,28)$ occurs also in the absence of B cells $(29$, 30 ), suggesting a need for a CD4-dependent humoral response. A comparable requirement for neutralizing antibody and/or direct $\mathrm{CD}^{+} \mathrm{T}$ cell-mediated effector function to supplement $\mathrm{CD}^{+} \mathrm{T}$ cell-mediated cytotoxicity also seems to underlie the recrudescence of lytic MHV-68 infection in the I-A ${ }^{\mathrm{b}-1-}$ mice. The marked susceptibility of IFN- $\gamma^{-/-}$and IFN- $\gamma$ receptor ${ }^{-/-}$ mice to the consequences of chronic MHV-68 infection (9) suggests an important function for this cytokine.

Depleting the $\mathrm{CD}^{+}$set in $\mathrm{I}-\mathrm{A}^{\mathrm{b}-/-}$ mice with recrudescent infection leads to increased virus titers and exacerbates the wasting disease (12), indicating that the eCTL exert a measure of control, but that they are insufficient. There was clearly a $\mathrm{CD}^{+} \mathrm{T}$ cell response to the recrudescent virus in the $\mathrm{I}-\mathrm{A}^{\mathrm{b}-/-}$ mice, directed particularly against the lytic phase p56 epitope (Tables 1 and 2, Fig. 5). The fact that the LDA frequencies (Fig. 6) were changed little could be a consequence of skewing the eCTL/CD8 ${ }^{+}$memory $\mathrm{T}$ cell ratio by high antigen load, as the activated eCTL are less likely to survive the 10 or more cycles of replication required to register in the LDA (31). The reason that persistent lymphocytic choriomeningitis virus (LCMV), but not MHV-68, causes CTL exhaustion may reflect differences in the extent of antigen stimulation. The recrudescence of MHV-68 may proceed as intermittent bursts of viral replication in focal sites of latency, rather than the overwhelming infection characteristic of the high dose immune paralysis in the LCMV model. Production of a lytic $\gamma-\mathrm{HV}$ at this level probably would kill the host before any immune exhaustion was observed.

Obvious questions about MHV-68 are why the CTL response in the $\mathrm{I}-\mathrm{A}^{\mathrm{b}-1-}$ mice should be more effective in the acute than in the persistent phase of infection, and why the eCTL in the spleen do not return in large numbers to the lung during viral recrudescence. One possibility with precedent in other HV infections $(26,32)$ is that CTL cannot recognize all types of virus-infected cells, at least in the absence of CD4 ${ }^{+} \mathrm{T}$ cell-derived cytokines. Alternatively, CTL surveillance of latently infected cells may not be sufficient to control the persistent infection without antibody to neutralize reactivated, free virus. Certainly I-A $\mathrm{A}^{\mathrm{b}-/-}$ mice show a gradual increase in the latent viral load (12) despite the presence of immune CTL that control the acute pulmonary infection. Preferential localization of most of the eCTL to the spleen when there is continual reversion to lytic cycle from a widespread latent pool may leave inadequate numbers to cope with the infection in the lung. A high viral load also may exaggerate any subtle effects on $\mathrm{CD} 8^{+} \mathrm{T}$ cell function mediated by the various analogues of host response genes (3) that are a common feature of the HVs (33-35). Further analysis of the functional status of the tetramer-positive $\mathrm{CD}^{+} \mathrm{T}$ cells during viral recrudescence should answer at least some of these questions.

We thank Vicki Henderson for assistance with the manuscript and Joe Miller and Kristen Branum for technical help. This work was supported by Public Health Service Grants CA 21765, AI38359, and AI42373, and by the American Lebanese-Syrian Associated Charities. 
P.G.S. was the recipient of a Medical Research Council (U.K.) traveling fellowship. G.T.B. is a C. J. Martin fellow of the Australian National Health and Medical Research Council (Reg. Key. 977 309).

1. Rickinson, A. B. \& Kieff, E. (1996) in Virology, eds. Fields, B. N., Knipe, D. M \& Howley, P. M. (Lippincott-Raven, New York), 3rd Ed., pp. 2397-2446.

2. Nash, A. A. \& Sunil-Chandra, N. P. (1994) Curr. Opin. Immunol. $6,560-563$.

3. Virgin, H. W., IV, Latrielle, P., Wamsley, P., Hallsworth, K., Weck, K. E., Dal Canto, A. J. \& Speck, S. H. (1997) J. Virol. 71, 5894-5904.

4. Stevenson, P. G. \& Doherty, P. C. (1998) J. Virol. 72, 943-949.

5. Tripp, R. A., Hamilton-Easton, A. M., Cardin, R. D., Nguyen, P., Behm, F. G., Woodland, D. L., Doherty, P. C. \& Blackman, M. A. (1997) J. Exp. Med. 185, 1641-1650.

6. Sunil-Chandra, N. P., Efstathiou, S. \& Nash, A. A. (1992) J. Gen. Virol. 73, 3275-3279.

7. Stewart, J. P., Usherwood, E. J., Ross, A., Dyson, H. \& Nash, A. (1998) J. Exp. Med. 187, 1941-1951.

8. Weck, K. E., Barkon, M. L., Yoo, L. I., Speck, S. H. \& Virgin, H. W., IV (1996) J. Virol. 70, 6775-6780.

9. Weck, K. E., Dal Canto, A. J., Gould, J. D., O'Guin, A. K., Roth, K. A., Saffitz, J. E., Speck, S. H. \& Virgin, H. W., IV (1997) Nat. Med. 3, 1346-1353.

10. Ehtisham, S., Sunil-Chandra, N. P. \& Nash, A. A. (1993) J. Virol. 67, 5247-5252.

11. Grusby, M. J., Johnson, R. S., Papaioannou, V. E. \& Glimcher, L. E. (1991) Science 253, 1417-1420.

12. Cardin, R. C., Brooks, J. W., Sarawar, S. R. \& Doherty, P. C. (1996) J. Exp. Med. 184, 863-871.

13. Moskophidis, D., Lechner, F., Pircher, H. \& Zinkernagel, R. M. (1993) Nature (London) 362, 758-761.

14. Doherty, P. C., Topham, D. J. \& Tripp, R. A. (1996) Immunol. Rev. 150, 23-44.

15. Zinkernagel, R. M., Bachmann, M. F., Kundig, T. M., Oehen, S., Pircher, H. \& Hengartner, H. (1996) Annu. Rev. Immunol. 14, 333-367.

16. Ahmed, R. \& Gray, D. (1996) Science 272, 54-60.
17. Altman, J. D., Moss, P. A. H., Goulder, P. R., Barouch, D. H., McHeyzer-Williams, M. G., Bell, J. I., McMichael, A. J. \& Davis, M. M. (1996) Science 274, 94-96.

18. Murali-Krishna, K., Altman, J. D., Suresh, M., Sourdive, D., Zajac, A., Miller, J., Slansky, J. \& Ahmed, R. (1998) Immunity 8, 177-187.

19. Flynn, K. J., Belz, G. T., Altman, J. D., Ahmed, R., Woodland, D. L. \& Doherty, P. C. (1998) Immunity 8, 683-691.

20. Butz, E. A. \& Bevan, M. J. (1998) Immunity 8, 167-175.

21. Buller, R. M. L., Holmes, K. L., Hugin, A., Frederickson, T. N. \& Morse, H. C., III (1987) Nature (London) 328, 77-79.

22. Bodmer, H., Obert, G., Chan, S., Benoist, C. \& Mathis, D. (1993) Eur. J. Immunol. 23, 1649-1654.

23. Tripp, R. A., Sarawar, S. R. \& Doherty, P. C. (1995) J. Immunol. 155, 2955-2959.

24. Hou, S., Mo, X. Y., Hyland, L. \& Doherty, P. C. (1995) J. Virol. 69, 1429-1434.

25. Kos, F. J. \& Engleman, E. G. (1996) Cell. Immunol. 173, 1-6.

26. Posavad, C. M., Koelle, D. M. \& Corey, L. (1998) Nat. Med. 4, 381-382.

27. Matloubian, M., Concepcion, R. J. \& Ahmed, R. (1994) J. Virol. 68, 8056-8063.

28. Battegay, M., Moskophidis, D., Rahemtulla, A., Hengartner, H., Mak, T. W. \& Zinkernagel, R. M. (1994) J. Virol. 68, 4700-4704.

29. Thomsen, A. R., Johansen, J., Marker, O. \& Christensen, J. P. (1996) J. Immunol. 157, 3074-3080.

30. Planz, O., Ehl, S., Furrer, E., Horvath, E., Brundler, M. A., Hengartner, H. \& Zinkernagel, R. M. (1997) Proc. Natl. Acad. Sci. USA 94, 6874-6879.

31. McMichael, A. J. \& O' Callaghan, C. A. (1998) J. Exp. Med. 187, 1367-1371.

32. Jonjic, S., Mutter, W., Weiland, F., Reddehase, M. J. \& Koszinowski, U. H. (1989) J. Exp. Med. 169, 1199-1212.

33. Hsu, D. H., de Waal Malefyt, R., Fiorentino, D. F., Dang, M. N., Viera, P., de Vries, J., Spits, H., Mosmann, T. R. \& Moore, K. W. (1990) Science 250, 830-832.

34. Moore, P. S., Boshoff, C., Weiss, R. A. \& Chang, Y. (1996) Science 274, 1739-1744.

35. Ahuja, S. K., Gao, J. L. \& Murphy, P. M. (1994) Immunol. Today 15, 281-287. 